\section{Connoisseurship Consumption Community and Its Dynamics}

\author{
Ronan Torres Quintáo \\ Instituto Federal de São Paulo, Jacareí, Sao Paulo, SP, Brazil \\ Eliane Pereira Zamith Brito \\ Fundação Getúlio Vargas, Escola de Administração de \\ Empresas de São Paulo, Sao Paulo, SP, Brazil \\ Russel W. Belk \\ York University, Schulich School of Business, Toronto, ON, Canada
}

\begin{abstract}
Purpose - This study aims to identify and explain the forces and tensions between the members of the connoisseurship consumption community and its dynamics.

Design/methodology/approach - Adopting a naturalistic inquiry approach, we immersed ourselves in the field, visiting and observing consumers and professionals in independent coffee shops in North America: Toronto, Montreal, Seattle, and New York from August 2013 to July 2014.

Findings - The research describes the connoisseurship consumption community and explains its forces, which are education, emulation and tensions between the members of the community.

Originality/value - Our findings explain the amateur consumer's behavior and the relationship of these amateurs with professionals and with the public during their consumption practices. We help to advance the study of heterogeneous consumption communities by revealing the tensions between the members of the community and the production of subcultural and social capital. Our research contributes to the consumer culture field by increasing knowledge of this social consumption phenomenon.
\end{abstract}

Keywords - consumption community, connoisseurship consumption, serious leisure, specialty coffee
Received on

02/16/2016

Approved on

09/13/2016

Responsible editor:

Prof. Dr. Guilherme de Farias

Shiraishi

Evaluation process:

Double Blind Review

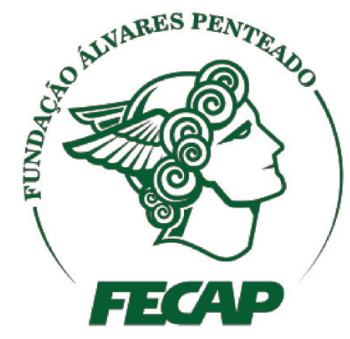

Review of Business Management 


\section{Introduction}

Researchers in the consumer culture field have investigated many types of consumption communities. Schouten and McAlexander (1995) introduced the subculture of consumption as an "analytic category for understanding the objects and consumption patterns with which people define themselves in our culture" (p.44). Some subculture of consumption studies address specific brands (Muniz \& O'Guinn, 2001), such as Star Trek (Kozinets, 2001), Harley Davidson (Schouten \& McAlexander, 1995), Apple (Muñiz \& Schau, 2014), or Macintosh (Belk \& Tumbat, 2004) that link members. Others explain the characteristics of temporary communities (Arnould \& Price, 1993; Belk \& Costa, 1998; Kozinets, 2002a), geographic communities (Weinberger \& Wallendorf, 2012), and heterogeneous communities (Thomas, Price, \& Schau, 2013).

The characteristics of the connoisseurship consumption communities have been described by some of these researches in the consumer culture field; however no research has yet identified and explored the forces and tensions between the members of this serious leisure consumption community and its dynamics. What are the dynamics of the connoisseurship consumption community? What are the forces and tensions that drive this serious leisure consumption community? Drawing on Stebbins' system (1979), we will focus this analysis on the members of the specialty coffee consumption community: the baristas (Professionals), connoisseurs consumers (Amateurs), and regular consumers (Public), to understand the dynamics of the community. In taking a socio-cultural approach, we interpret our qualitative data on specialty coffee consumption by drawing on key concepts of serious leisure and consumption communities.

Prior consumer research has studied serious leisure consumption pursuits among climbers of Mount Everest (Tumbat \& Belk, 2011), collectors (Belk, 1988), Star Trek aficionados (Kozinets,
2001), members of running clubs (Thomas et al., 2013), mountain man rendezvous re-enactors (Belk \& Costa, 1998), and do-it-yourself home improvers (Moisio, Arnould, \& Gentry, 2013), and have addressed amateur consumer behavior (Belk, 1995; Karababa \& Ger, 2011; Martin \& Schouten, 2014). Less attention has been focused on the forces that drive the serious leisure consumption communities and connoisseurship communities.

The context of specialty coffee was chosen for study because it has several important features such for consumers' (anti-corporate) experiences of globalization (Thompson \& Arsel, 2004), emotional branding, and doppelgänger brand image (Thompson, Rindfleisch, \& Arsel, 2006), hegemonic brandscapes (Thompson \& Arsel, 2004), boycotts, and outsourcing of politics (Simon, 2011), Coffee culture and consumption have been studied in Japan (Grinshpun, 2013), and coffee's role in global consumer culture in Scandinavia (Kjeldgaard \& Ostberg, 2007). Furthermore, specialty coffee allows for a variety of serious leisure pursuits, like professional specialization (baristas or other professionals who brew coffee), training (public coffee cupping courses, coffee tastings, coffee seminars), equipment acquisition (espresso machines, grinders, brewing equipment), competitions (world and regional barista championships, brewers cup championships, cup tasters championships), and consumption with different audiences (public, friends, family, coworkers).

On the basis of our qualitative study of connoisseurship consumption in the specialty coffee context, we develop a broader theoretical account that builds on the notion of consumption community. We argue that connoisseur consumers participate in the connoisseurship consumption community, which is described using Stebbins's (1979) P-A-P system - professional - amateur - public. This heterogeneous community (Thomas et al., 2013) is composed of outstanding baristas (professionals who prepare the coffee), connoisseurs (amateurs), and regular consumers 
(public). The forces that drive the community, as identified in this study, are the production of subcultural and social capital, emulation, and tensions between the members of the community regarding the subcultural and social capital acquired. In the next section, we review theory about connoisseurship consumption, serious leisure, and amateurs, define subculture of consumption and heterogeneous community, and describe the context of the research. After that, we present the methods used in our qualitative research, and describe our research findings. Finally, we discuss the results and consider future research.

\section{Connoisseurship Consumption and Serious Leisure}

Connoisseurship is expressed through consumption practices, even if the object itself is widely consumed, as in the case in the coffee context, or ignored by other consumers. Through connoisseurship, consumers produce a certain subjectivity (Holt, 1998). Connoisseurship means applying a highly nuanced schema in order to understand, evaluate, and appreciate consumption objects (Holt, 1998). According to netnographic research conducted by Kozinets (2002b) in the 1990s, coffee connoisseurship, taste refinement practices increased and were frequently taught on the online newsgroup that he followed. He notes that "Starbucks simultaneously raised the consciousness of coffee connoisseurship, the demand for coffee shops, the sales of coffee-flavored ice cream and cold drinks, and the market price of a cup of coffee" (2002b, p.66). Elliot (2006) reinforces Kozinets's findings. According to Elliot, "Starbucks distributes a twenty-two-page pocket-sized guide that provides thirty-eight key terms necessary to order coffee" (2006, p.233), distinguishing aromas and shades of taste and allowing connoisseurs to demonstrate their education. She also explains that coffee connoisseurs use "geography to illustrate both their knowledge and their taste preferences" and by ordering Sumatra, Kona, New Guinea
Peaberry, Brazil Ipanema Bourbon, and the like, the coffee connoisseur "orders a place in a cup" (Elliott, 2006, p.233).

To develop their consumption practices, the members of connoisseurship consumption community engage in serious leisure pursuits. Leisure is an "uncoerced, contextually framed activity engaged in during free time, which people want to and, using their abilities and resources, actually do in either a satisfying or a fulfilling way (or both)" (Stebbins, 2012, p.4). Gelber (1999, p.7) points out three fundamental assumptions about the nature of leisure activities: 1) they take place in time that is free from work, which includes personal, familial, and home care activities necessary for life maintenance; 2) they are voluntarily undertaken; and 3) they are pleasurable. Gelber emphasizes, "Activities that are understood as work, including nonremunerated labor such as family care or schoolwork, no matter how pleasurable, are not leisure" (1999, p.7). For many consumers, leisure is a way to find personal fulfillment, identity enhancement, self-expression, and the like, and leisure becomes an opportunity to improve their own work (Stebbins, 1982). Seeking to adopt those forms of leisure that will yield the greatest payoff, connoisseur consumers "reach this goal through engaging in serious rather than casual or unserious leisure" (Stebbins, 1982, p. 253).

Participants involved in serious leisure identify strongly with their chosen pursuits, and they invest significant personal effort based on special knowledge, training, or skills, and sometimes all three. Some of them tend to have careers in the areas of their serious leisure endeavors, becoming professionals (Stebbins, 2007). Serious leisure practitioners "are not dependent on whatever remuneration they derive from it" and "they are freer than breadwinners to renounce their leisure," but they are usually "more obliged to engage in their pursuits than are their unserious counterparts" (Stebbins, 1982, p.255). According to Stebbins (2007), amateurs, such as hobbyists and volunteers, participate in one type of serious leisure. They pursue an activity chosen 
because of its strong appeal (Stebbins, 1982). They refuse to remain a "player, dabbler, or novice at this leisure, searching for durable benefits, transforming the activity into an avocation in which the participant is motivated by seriousness and commitment" (Stebbins, 1982, p.258).

Connoisseur connoisseurs are nevertheless amateurs (Ahuvia, 2005; Holt, 1998; Kozinets, 2002b). But even for amateurs, there is always a public that can be composed of friends, relatives, neighbors, or other amateurs engaged in the same activity. The public learns by "interacting with the work and, frequently, with other people in relation to the work" (Becker, 1982, p.64). Amateurs are oriented "by standards of excellence set and communicated by those professionals" (Stebbins, 1982, p. 259). In the P-A-P system, the term "amateur" can be used only with activities that constitute, for some, a professional work role. There have always been professionals, but what is new is the rise of the amateur (Hennion, 2004, p.142). Professionals often enjoy a great deal of respect, not only because of their high "subcultural capital" (Thornton, 1996), but also from their role in defining and creating it. What used to be just a hobby now has become a pseudoprofession. When professionalization occurs (see Larson, 1977), "those who retained their serious, albeit part-time, commitment to the activity were gradually transformed into amateurs" (Stebbins, 1982, p.263). However, amateurs cannot perform the activities as outstanding professionals in their fields do (Stebbins, 1979). Becker (1982) confirms this in the art world, explaining that amateurs do not know all the things that wellskilled professionals know. The Stebbins' P-A-P system is based on rituals (Rook, 1985) performed in a way that strengthens the connections between the system's participants helping to build a connoisseurship consumption community.

\section{Connoisseurship Consumption Community}

A connoisseurship consumption community is a subculture of consumption, which means that it is a "distinctive subgroup of society that self-selects on the basis of a shared commitment to a particular" consumption activity with "an unique ethos, a set of shared beliefs and values, unique jargons, rituals, and modes of symbolic expression" (Schouten \& McAlexander, 1995, p.43). However, differently from other communities, members of the connoisseurship consumption community (professionals, connoisseurs and regular consumers) are committed to the serious leisure pursuits (Stebbins, 1982). The relationship developed among them can be explained by the Stebbin's P-A-P system. As Thomas, Price, and Schau (2013) learned in the distance running community, the connoisseurship consumption community members are heterogeneous and have multiple producers across many types of products. Thomas et al. (2013) define heterogeneous community as "an assemblage of diverse actors, including consumers, producers, and social and economic resources" and "these actors vary in how they orient towards the community, in how they enact their community roles, and in the meanings they construct in relation to the community" (Thomas et al. 2013, p.1011).

Coffee consumers have multiple orientations toward the manner of brewing and drinking coffee. Producers represent a large coffee industry that supports and participates in the community. Resources such as highindependent coffee shops brands, types of coffee, coffee institutions and associations, Internet and places are integral to the community. Using terms developed by Thomas, et al. (2013) to classify consumption communities studied in consumer and marketing research, the connoisseur consumer community is activity-focused (connoisseurship coffee consumption) and enduring, and it has broad appeal, low barriers to entry, a welcoming environment, hybrid dispersion (interaction of the member happen in person and online), a synergistic marketplace orientation (coffee consumers, baristas and other coffee professional work collaboratively for the benefit of the community), a complex structure of resource 
dependency, prominent collective belonging, and heterogeneity.

According to Thomas et al. (2013) the focus of consumption communities research is still on singular producers. Moreover prior consumption community research has not identified the forces that drive the dynamics of the community. In the connoisseurship consumption community, these forces are essential to reinforce and boost their differentiation. Subcultural ideologies are a means by which connoisseur consumers "assert their distinctive character and affirm that they are not anonymous members of an undifferentiated mass" (Thornton, 1996, chapter 1, paragraph 10). Connoisseur consumers search for exclusivity "through the purchase of distinctive clothing, foods, automobiles, houses, or anything else that individuals may believe, will in some way set them off from the mass of mankind" (Leibenstein, 1950, p.184). This is called the "snob effect" by Leibenstein (1950). In the case of connoisseur consumers, they can be seen to continuously develop distinct connoisseurship practices in order to differentiate themselves from other consumers. Although many characteristics of consumption communities have already been described (e.g.; Belk \& Costa, 1998; Cova, 1997; Kozinets, 2001; Muniz \& O'Guinn, 2001), the dynamics of connoisseurship consumption communities and the interplay between their members have not been explored yet.

\section{Spectialty Coffee Context}

The specialty coffee market segment, which emerged in 1980 (Roseberry, 1996) and has topped the retail sales of traditional products since the beginning of the 2000s (Cassia, Fattore, \& Paleari, 2006), was developed by Starbucks as the principal company in the 1990s and at the beginning of the 2000s (Hartmann, 2011). Companies such as Peet's, created in 1966 (with 217 locations in the United States), and Starbucks (with fifteen thousand stores worldwide) in the specialty coffee market, offer new opportunities for consumers to taste something different than regular coffee. The term "specialty coffee" was first coined by Erna Knutsen, of Knutsen Coffee Ltd., in a 1978 speech, to refer to beans with unique flavor profiles that were produced in special geographic microclimates. Presently, specialty coffee is "defined by the quality of the product, whether green bean, roasted bean, or prepared beverage, and by the quality of life that coffee can deliver to all of those involved in its cultivation, preparation and degustation" (Rhinehart, 2009, p.3). As articulated by the Specialty Coffee Association of America (www. scaa.org), specialty coffee is of superior quality. The expression "superior quality" is used in the marketplace to differentiate specialty coffee from regular coffee.

Although Starbucks played a major role in the 1990s in spreading the market of connoisseur consumption practices and helping to increase the number of coffee connoisseurs, nowadays coffee connoisseurs no longer try coffee in coffee shop chains (e.g., Starbucks, Peets, Seattle Coffee) because of their uniformity and predictability (Ritzer, 2007), the connoisseurs' perception of their low coffee quality, and the coffee shop chains' "commodity logic" (Thompson \& Arsel, 2004, p.639). Coffee shop chains represent mass consumption. Connoisseurs prefer high-end independent coffee shops (HEICS). In 2002, Kozinets predicted that the characteristics of the new HEICSs would be preferable among this new type of coffee connoisseur consumer:

If the Starbucks brand is becoming passé, a mere symbol ('*\$') of overroasting, a good place to read and hang out but not to drink coffee, then the next generation of coffee brands to tap into the discriminating coffee ethos will likely thrive by positioning on the opposite end of these dimensions: human, passionate, roasted right, free, alive, locally involved, existentially complete. (Kozinets, 2002b, p.70). 
In the HEICS craft tradition, consumers and professionals can retain some control over every stage, or almost every stage, of manufacture, "and thereby gain a far more satisfactory relationship with the product" (Miller, 1997, p. 140). HEICSs promote a "conspicuous handmade image, explicit separate from the products of mass consumption, and immediately recognized as a quality product" (Miller, 1997, p. 140). In HEICSs, consumers can taste different high-quality coffees prepared by well-trained baristas who can help and guide them during their tasting rituals, using cuttingedge equipment.

\section{Data Collection and Methods}

To understand the dynamics of the connoisseurship consumption community, the first author immersed himself in the field, visiting and observing consumers in independent coffee shops in North America: Toronto, Montreal, Seattle, and New York from August 2013 to July 2014. Adopting a naturalistic inquiry approach (Belk, Sherry \& Wallendorf, 1988), he got inside the specialty coffee community and increased his coffee knowledge and taste as a fully participating member of the culture of consumption (Arnould \& Wallendorf, 1994). This presence in the coffee shops and in online social media helped him gain acceptance and trust inside the community. At the beginning of the research, to identify coffee connoisseur consumers, he used as a criterion sampling strategy (Miles \& Huberman, 1994) consumers at HEICSs who drank coffee without milk and sugar, who interacted with the barista, asking questions about the coffee. After this initial phase, based on the first interview experiences with connoisseur consumers, he used a purposive sampling design as well as snowball sampling (Miles \& Huberman, 1994).

The first author conducted intensive and open-ended interviews, as suggested by Rook (1985), based on the long interview method (McCracken, 1988). The interviews, conducted as special conversations, were unstructured with open-ended questions, and were conducted on-site (independent coffee shops) using a phenomenological approach (Thompson, Locander, \& Pollio 1994). The interviews were recorded and transcribed. The data set includes 20 on-site, in-depth coffee consumer interviews (1,668 minutes, Table 1$)$, and 11 in-depth coffee professional interviews (855 minutes, Table 2); 377 pages of field notes; and 551 photographs. $\mathrm{He}$ also visited and observed consumers in 49 independent coffee shops: nine in Seattle, nine in New York, 28 in Toronto, two in Montreal, and one in Niagara. He also conducted interviews and observations at the $27^{\text {th }}$ annual exposition of the Specialty Coffee Association of America hosted in Seattle.

A netnography was also conducted, following the recommendations of Kozinets (2014) starting in August 2013. We followed the online interactions of connoisseur consumers and coffee professionals on Twitter and Instagram and also participated by interacting with them online. It eventually became evident that Twitter is the specialty coffee community's preferred online social media outlet and the emphasis switched to following the online interactions of connoisseur consumers and coffee professionals on Twitter and Instagram together with online interactions with them. At the same time, some connoisseur consumer blogs and many related blogs run by professionals provided much useful information. During the data collection the second and third authors interacted with the first author and jointly interrogated the written research material. The body of qualitative data was interpreted using a hermeneutic approach (Thompson, 1997), comparing consumers and professional's practices studying "differences between newcomers and those who have long been members" (Belk, Fischer, \& Kozinets, 2013, p.148) of the connoisseurship consumption community. In the next section, we present the findings of the research: the relationship between community members, production of subcultural and social capital, enactment tensions, consumer status game and the discussion. 
Table 1

Profile of key coffee consumer informants

\begin{tabular}{|c|c|c|c|c|c|c|}
\hline N. & Pseudo-nym & $\begin{array}{l}\text { Profile of the } \\
\text { Consumer }\end{array}$ & Occupation & Age & $\begin{array}{c}\text { City of } \\
\text { Residence }\end{array}$ & $\begin{array}{c}\text { Nation- } \\
\text { ality }\end{array}$ \\
\hline 1 & Frank & $\begin{array}{l}\text { Advanced } \\
\text { Connoisseur }\end{array}$ & Website designer & 44 & Seattle & American \\
\hline 2 & Suzy & Advanced & Biochemist & 28 & Toronto & Canadian \\
\hline 3 & Alan & Advanced & Vendor Engineer & 51 & Seattle & Brazilian \\
\hline 4 & John & Advanced & Marketing manager & 32 & Seattle & American \\
\hline 5 & Greg & Advanced & Architect & 37 & Toronto & Polish \\
\hline 6 & Laura & Advanced & Executive searcher & 61 & Toronto & American \\
\hline 7 & David & Connoisseur & Phd Student & 39 & Toronto & American \\
\hline 8 & Jane & Connoisseur & Financial controller & 30 & Seattle & American \\
\hline 9 & Maria & $\begin{array}{l}\text { Beginner } \\
\text { Connoisseur }\end{array}$ & Not working (classics) & 31 & Seattle & Canadian \\
\hline 10 & Paul & Beginner & Undergraduate student & 21 & Toronto & Chinese \\
\hline 11 & Kevin & Beginner & Undergraduate student & 21 & Toronto & Chinese \\
\hline 12 & Bob & Beginner & Unemployed & 29 & Seattle & American \\
\hline 13 & Jacquie & Public & Pastry Chef & 28 & Toronto & Canadian \\
\hline 14 & Hunt & Public & Media communication & 25 & Seattle & American \\
\hline 15 & Kate & Public & Undergraduate student & 21 & Toronto & Chinese \\
\hline 16 & Joana & Public & Enterprenieur & 56 & Toronto & Canadian \\
\hline 17 & Vera & Public & Backery & 26 & Toronto & Canadian \\
\hline 18 & Elizabet & $\begin{array}{c}\text { Regular } \\
\text { Consumer }\end{array}$ & Manager & 40 & Seattle & American \\
\hline 19 & Robson & Regular & Aquitect & 40 & Seattle & American \\
\hline 20 & Jackie & Regular & Undergraduate teacher & 50 & Toronto & Canadian \\
\hline
\end{tabular}

Table 2

Profile of key coffee professional informants

\begin{tabular}{ccccc}
\hline N. & Pseudonym & Age & Occupation & City of residence \\
\hline 1 & Albert & 26 & Barista & Seattle \\
2 & Claudia & 25 & Barista & New York \\
3 & Scott & 26 & Barista & Toronto \\
4 & Richard & 32 & Barista & Toronto \\
5 & Philip & 30 & Barista & Toronto \\
6 & Kent & 32 & Barista & Toronto \\
7 & Jack & 32 & Manager & New York \\
8 & Steve & 32 & Manager and barista & New York \\
9 & Harris & 35 & Franchising manager & Toronto \\
10 & Andrew & 32 & Roaster & Seattle \\
11 & Adam & 35 & Coffee shop owner & Toronto \\
\hline
\end{tabular}




\section{The Connoisseurship Consumption Community Dynamics}

Coffee connoisseurship consumption is performed as serious leisure, and therefore, a particular community emerges within and across high-end independent coffee shops (HEICSs). Participants in serious leisure pursuits (coffee connoisseurs) tend to strongly identify with their chosen pursuits and also develop a unique ethos and shared core values. Amateurs tend "to develop subcultures composed of special beliefs, values, moral principles, norms, and performance standards" (Stebbins, 1982, p.257). The informants meet regularly with baristas and other coffee consumers in HEICSs to perform tasting rituals, sharing and reinforcing the core community values and the ideal behaviors of the group, which are guided by professional standards. As amateurs, coffee connoisseur consumers have the "willingness to work toward perfection" (Stebbins, 1979, p.41). They have consumption practices that help tighten ties among the community members. In the coffee shops, the informants reveal their membership in the specialty coffee community through their coffee choices, social interactions, language, expressions, and conversations with baristas and others. Stebbins (1982, p.257) explains that serious leisure participants "are inclined to speak proudly, excitedly, and frequently about [their focus of interest] to other people, and to present themselves in terms of them when conversing with new acquaintances."

They are committed to the serious leisure pursuits, and if the members of the community are not involved enough, they change groups. Alan is no longer a member of one coffee club because the members are not involved with coffee like him: "Of course, everybody likes coffee, but they, they are not crazy about coffee, they are not obsessive to learn everything about coffee [like me]." The informants are interested in developing their own personal skills and abilities. The linkage between the members is through their knowledgeable consumption practices, which represents an important "social process by which the meaning of the community is reproduced and transmitted within and beyond the community" (Muniz \& O'Guinn, 2001, p. 421). Figure 1 presents the members of the connoisseurship consumption community and its forces which are education to increase subcultural and social capital, emulation and tensions between the members of the community regarding the subcultural and social capital acquired.

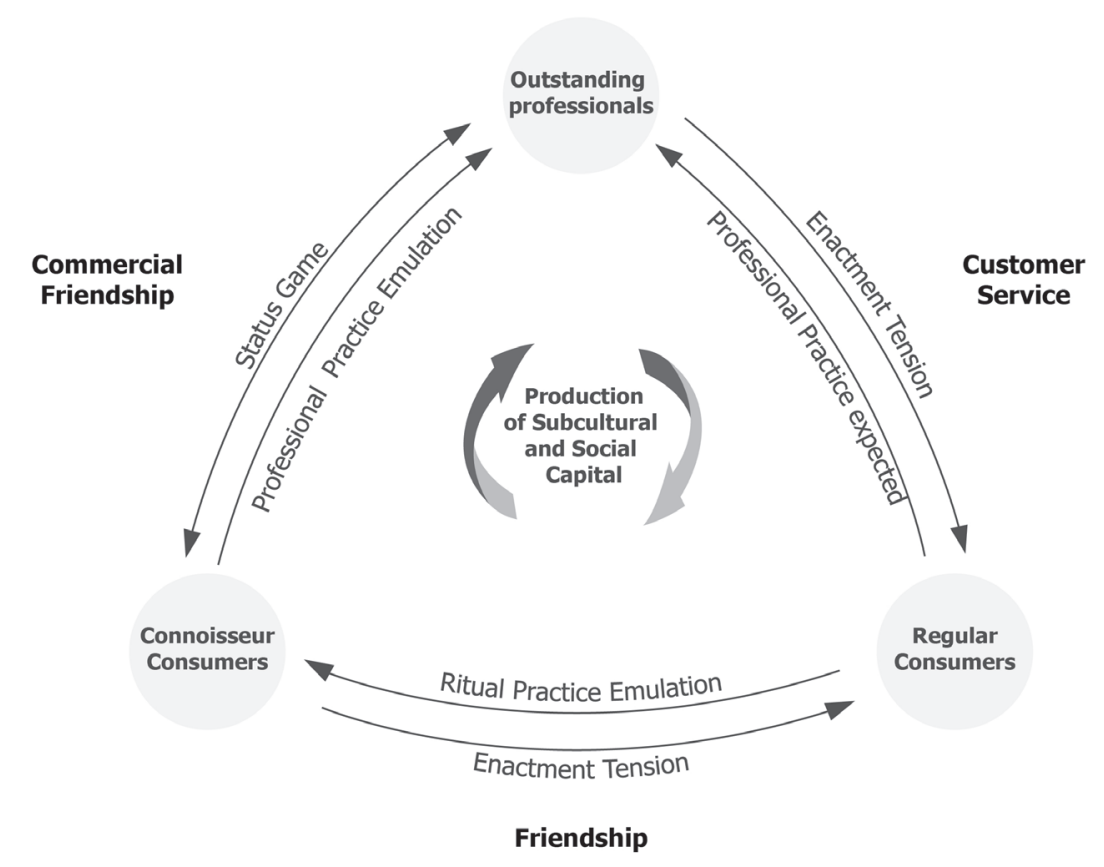

Figure 1. Connoisseurship consumption community. 


\section{I The relationship between community members}

As in the river magic experience (Arnould \& Price, 1993), a community is developed among customers and people who work in the specialty coffee market. HEICS owners and baristas develop commercial friendships (Thompson, Rindfleich \& Arsel, 2006; Price \& Arnould, 1999) with connoisseur consumers. For Frank, "It's just the people I know in Seattle." John revealed that he is "really good friends with all the baristas. You know, at this point, they're just people that I just really have been kind of friends with." In the postmodern consumer culture, which is fragmented and individuated (Firat \& Venkatesh, 1995), Thompson and Arsel (2004) explain that consumers are able to "forge an ephemeral sense of interpersonal connection via common consumption interests" (p.639), seeking "a palliative for the distressing feelings of isolation, inauthenticity, and depersonalization" (p.640). David expresses the sense of community in the specialty coffee and the importance of the barista in his social life:

There is a nice sense of community in the specialty coffee shop. There are other people who are also regulars, and so by going there, I just have encounters with friends of mine, but I haven't planned it. So, it is a social occasion as well. It's such a nice community that many of the baristas have become my friends. Those individuals have become important to me personally.

This sense of community happens also between the baristas and other coffee professionals, and also between connoisseurs and regular coffee consumers. Steve revealed that "no matter where I am in the world, I will have a friend." The informants who are in the advanced connoisseurship level explained that they make a lot of friends who were regular consumers who were interested in coffee and want to learn about it. The friendships between connoisseurs and regular consumers are part of the community ethos. Connoisseur consumers' friends also encourage them to go forward. It happened with Suzy. Her friends told her to create a coffee blog and write about her coffee experiences.

"So I guess in 2004 when I started to get more into it [specialty coffee consumption culture], I would talk about coffee to my friends, and my friends would say, 'Well, why don't you write about this?' Because I would keep a little notebook about what I drank, right? Then I said, 'I don't really want to.' At that time there was also starting of these internet sites and blogging. So my friends would keep encouraging me to, maybe you should write it on the internet".

Coffee club leaders make many friends with people who approach them because of their interest in coffee. They build long relationships. Regular consumers trust and rely on connoisseur consumers to take the first steps in the specialty coffee consumption culture. However, the weak link of the community is between the baristas and regular consumers, because they are not involved or immersed in the specialty coffee culture. For regular consumers, the beverage represents a source of energy, or a break at work (grab and go: get the coffee quickly in the coffee shop and go), or even a reason to socialize. Regular consumers usually do not know about HEICSs or even the barista's name. In the HEICS where we met, I asked Joana what the barista's name was. Surprised, she said, "Why should I know?” Joana, Robson, and Elizabet regularly go to independent coffee shops (less often than coffee connoisseurs), but they just want to have their Americano or Cappuccino and socialize (Joana), or do work at the tables in the coffee shop (Robson and Elizabet). Like the Café Flâneurs (the social and creative buzz) described by Thompson and Arsel, "their aim is not to build an enduring relationship or to become part of a community; rather, they 
are seeking a more intimate, but transient, social encounter that offers a brief glimpse into the life of another" (2004, p.635). The customer service expected by regular consumers is the same type of service found in any coffee chain: smiles, greetings, politeness, education, attention, efficiency, and so on.

\subsection{Production of subcultural and social capital}

The education of Professionals and consumers has been important in the specialty coffee market in the last couple of decades, helping to increase the number of coffee connoisseur consumers and the size of the specialty coffee community. The offline and online interaction between connoisseurship consumption community members help connoisseur consumers to produce and increase their subcultural (Thornton, 1996) and social capital (Bourdieu, 1984; McQuarrie, Miller, Phillips, 2013). Field notes and introspection revealed a desire to taste different high-quality espressos, prepared by well-trained baristas, and to discuss espresso with other coffee connoisseur consumers in person or online (via social media). Furthermore, through cuppings, and education seminars available in the specialty coffee market, consumers test their taste skills. Lectures, annual events, and courses provided by many market actors (the most important being the Specialty Coffee Association of America or SCAA), Internet courses (e.g., ChefSteps, 2014), and tutorials (e.g., INeedCoffee: Chemex Coffee Brewing: History and Tutorial) increase the specialty coffee market and the number of connoisseur consumers. In the 1980s, during the expansion of the specialty market segment, the regional roasters, and others new to the specialty coffee trade, expanded the market in many ways, including "running educational seminars to cultivate a more detailed knowledge of coffee among retailers, expecting that they in turn would educate their customers" (Roseberry, 1996, p.129).

The connoisseurship consumption community is heavily based on online communities where participants share information, knowledge, and experiences and have instantaneous feedback. Online communities are "contexts in which consumers often partake in discussions whose goals include attempts to inform and influence fellow consumers about products and brands" (Kozinets, 2002b, p.61). As Belk (2013) notes, the participants are from diverse social, age, and economic strata, and they build less intimate relationships compared to close friends and neighborhoods. Coffee shops are offline third places (Oldenburg, 1997), while online communities are online third places "that provide an anchor for online aggregate sense of self that is shared with and mutually constructed by other regulars" (Belk, 2013, p.487). Belk explains, however, that "physical co-presence is not needed for a rich sense of imagined community" (2013, p.486). The shared understanding in an online community of what is good coffee, an outstanding barista, or a quality HEICS is "an exercise in forming a coherent sense of aggregate self with friends" (Belk, 2013, p.4878). Online specialty coffee communities are the virtual places where connoisseur consumers improve their knowledge as well as their subcultural and social capital. Alan explains how Twitter helps him to gain more subcultural capital.

The coffee world here in the US is totally based on Twitter. I've got in Twitter, and everybody gets in contact on Twitter, all the baristas. You must follow people on Twitter (...) I guess that I follow almost one-thousand people on Twitter in the coffee world. There are some people in Europe that I consider geniuses (...) There is another guy in England. There is another one in Ireland. Once, due to my work, I went to Ireland, and I got in contact with him, and I asked for recommendations of coffee shops in Ireland. He answered me, and I visited his coffee shop and others. And thereafter, you keep developing these kinds of relationships. 
Social media and the rise of the blogosphere have enabled the consumer (and other actors in the field, such as baristas, coffee house owners, and roasters) to acquire knowledge and develop tastes and connoisseurship practices. Alan's experiences indicate how subcultural capital is converted into social capital. Belk explains that "the possibilities of digital sharing online foster feelings of community and aggregate sense of self, even with others we would not recognize in person" (Belk, 2013 , p.486). In the social media world, coffee connoisseurs reach both a specific audience (coffee professionals and coffee connoisseurs) and a more mass audience (friends, family, and so on), thereby increasing their social capital.

\subsection{Enactment tensions}

In one coffee group meeting, a new member of the group showed up and introduced himself to the other participants sitting at the table. Although he said that he loved coffee and had been drinking great coffee in many different coffee shops for many years, after he had left the meeting, the participants explained that he did not know anything about coffee and that he had a long way to go before starting to understand what real coffee is. The participants in the coffee meeting thus revealed the "hierarchical social structures based on the relative statuses of the individual members" (Schouten \& McAlexander, 1995, p.48) in the connoisseurship coffee subculture of consumption. According to them, the new member drank Cappuccino, listed coffee shops that are not good places, and referred to poor coffee beans. He failed to appreciate the symbols of the community: drinking coffee without milk, knowing the best coffee shops, drinking "real" coffee, taking into consideration the importance of well-skilled baristas, and so on. "The structure of the subculture, which governs social interaction within it, is a direct reflection of the commitment of individuals" (Schouten \& McAlexander, 1995, p.48), and it reflects the common values of the community. Referring to the new member of the coffee meeting group, one participant said:
"He lives in [specific neighborhood]. He doesn't really know where the good coffee shops are. The place he thinks is good coffee is really actually quite terrible coffee. He says, "I'm trying this group, I'll try this." He's never been to [specific coffee shop] and he's lived in Seattle for seven years, never been to [specific coffee shop]. I really can't hold much of a coffee conversation with him because he's got a long way to go to get to there. I can hold a conversation with these guys".

In the process of legitimizing the community, members "differentiate between true members of the community and those who are not, or who occupy a more marginal space. . . They do not deny membership, but like most communities they do have status hierarchies" (Muniz \& O'Guinn, 2001, p.419). This tension takes place between those whose purpose is to improve their coffee skill and knowledge, and those who want to socialize in the coffee shop as a third place. It usually happens between regular consumers (Public) or beginner coffee connoisseurs, and intermediate and advanced connoisseur consumers (Amateurs). Alan used to be a member of a coffee club, which is a social group open to regular and connoisseur consumers that regularly meets in coffee shops to drink coffee and socialize. He explained what happened with him and the group:

"They drink Starbucks, or drink [coffee shop name], which is the worst one here in the city, but there are people who like it and there are people who don't care about it, understand? And people who go to the Coffee Club, nowadays, I don't, I don't have anything against them, but I am a person, as I told you, introspective, and I am an antisocial person, and I am a person. So I lost the willingness to go to the Coffee Club meetings, because the interest of the people who go is different than mine". 
The difference in purpose was the main issue for Alan when he decided to leave the coffee club. He was not concerned about socialization; he wanted to improve his own skill. As in the running community, there is a tension between participation (regular consumers) and performance (connoisseur consumers), such that "some community members devalue the enactments of others" (Thomas et al., 2013, p. 1020).

Another enactment of tension happens between baristas and regular consumers, who usually order drinks that mix coffee with milk, sugar, caramel, or chocolate. Michael Ryan tweeted: "It's getting harder for me to make myself sick dialing in and then watch someone add tons of sugar to their latte without even trying it" (@ michaelcmryan, October, 13 of 2014). The blog called the Bitter Barista reveals the "thoughts from behind the counter, and other reasons why I hate you." The baristas joke about the regular consumers' coffee preferences. They like candy bars, pumpkin spice lattes, peppermint-eggnog lattes, which baristas do not appreciate. They prefer coffee, or better, they "recommend coffee." Charles Babinski, who was a top-2 barista in the United States in 2013 and 2014 and the owner of Go Get Em Tiger (an HEICS in Los Angeles, California) deals with this enactment tension in a different way. During his SCAA lecture in 2014, he stated that many consumers want to drink mixed drinks as served in coffee shop chains. They ask for it all the time. To release the consumers pressure and attend their desire, he decided to make "a day in the year for fun mixing everything." In 2014, he prepared a different menu for Thanksgiving Day (from $8 \mathrm{am}$ to $2 \mathrm{pm}$ ) and posted it on Instagram. The title of the post was, "this is real." The menu was "peppermint mocha, chestnut praline latte, eggnog latte, pumpkin spice latte, gingerbread latte" (November 23, 2014).

\subsection{Consumer status game}

The coffee connoisseur and the barista have an intertwined relationship. The latter is essential to the former performing the taste transformation ritual, and the former pushes the barista to the edge of their everyday work. They develop a commercial friendship; however, a status game (Holt, 1998; Üstüner \& Thompson, 2012) is also established between connoisseur consumers and baristas. Connoisseur consumers develop their subcultural capital in the specialty coffee field, and they seek to acquire prestige with professionals in a particular status game structured around connoisseurship practices. They win prestige through the performance of the taste transformation ritual, and some of them draw on their resources of subcultural capital to compete for status with the baristas. Subcultural capital distinguishes connoisseurship consumption members from regular consumers. With subcultural capital, connoisseur consumers negotiate and accumulate status within their social world. Thornton affirms, "Subcultural capital confers status on its owner in the eyes of the relevant beholder" (1996, chapter 1, paragraph 28). The status game happens most often between the coffee connoisseur and the barista when coffee knowledge comes to the scene and enters the conversation and practices. Suzy explained that the situations are sometimes uncomfortable because her coffee knowledge can make it difficult to engage in a deep conversation with baristas about coffee:

"I'm able to talk more to them [baristas] about it [coffee], but at the same time it's almost difficult because they see it as fashion, and they see me as just a consumer. So why would I, a consumer, be as knowledgeable as them? It's almost like they don't take me seriously, and so that it's also one of the reasons why I don't tell people, "I will write about you [on my coffee blog]," is because I don't want them to think that I know more than them. I don't know more than them, but I want to find out. A deep perception of me may change". 
Connoisseur consumers don't "enact (and enforce) their dominant position in the relationship" (Üstüner \& Thompson, 2012, p. 807) with baristas. They want to be treated in a special way and acknowledged for not being regular consumers. They want to be recognized by community members as someone unique and distinct from the others. Outstanding baristas are the gateway for connoisseur consumers to improve their taste and increase their subcultural and social capital. They follow connoisseur consumers on Twitter, Instagram, and other social media, commenting on and retweeting their posts, and baristas also invite them to specialty coffee community events. For example, Frank received a free pass for the SCAA event in Seattle. And Alan, Frank, and Marcos were invited to the special competitions in their cities), parties, and meetings.

Some coffee connoisseur consumers, when they do not know the barista or go to a coffee shop for the first time, use hints and cues to mediate the relationship, and help the barista understand that they are a differentiated consumer who appreciates coffee and wants something special. Smith wrote a post explaining how to "validate yourself with the barista" (2011, March 15). The purpose is to be treated differently from a regular consumer. He explains that "the barista is making hundreds of drinks a day and most of their customers will happily accept defects without complaining. How do you validate yourself? Ask a question that lets them know you are an espresso aficionado." (2011, March 15). He also gives another tip. If the consumer wears t-shirts about coffee and also engages in a serious conversation, revealing that they are a coffee aficionado, the barista can give excellent espressos, and even free ones. I used these validation strategies many times in the U.S. and Canada. Indeed, the customer service changed when I used this strategy". However, depending on the independent coffee shop, the strategy does not always work so well. Smith used this strategy in another city, but it was not as he expected. He did not get any better espresso. Actually, his behavior was considered offensive by the baristas of the city. One barista of the city posted on Twitter a message criticizing Smith's approach using the "validate yourself with the barista" strategy: "the moment when a coffee guy comes to your cafe and starts name dropping and asking coffee questions instead of identifying himself ugh." However, there are consumers who try to show off. In a podcast, Michael Ryan, a barista and roaster at Caffee Ladro, Seattle, explained that there are consumers who try to show off their coffee knowledge to the barista. They try to win a kind of coffee information competition of "who knows more about coffee", "The coffee geek is the person who is there to show you how much they know, and it is another type of customer you just have to roll with it. You got to take it and kind of just let it roll off your back" (Audio Café, 2014, February 4).

\section{Discussion}

Connoisseurs and regular consumers, and outstanding professionals take part in the community, producing subcultural and social capital online and offline through the relationships that they develop. The relationship between regular consumers and outstanding professionals is looser than the other two, because what is expected by the consumer is customer service at a good professional standard. The tension between regular consumers, professionals, and connoisseur consumer occurs as a result of the differences in their consumption practices. In fact, regular consumers usually do not know how to identify outstanding professionals, or they are not concerned about being able to identify outstanding professionals. Usually, the first person who inspires them to get deeper in the community is a connoisseur consumer. Regular consumers who want to join the connoisseurship community try to emulate the coffee connoisseurs' ritual practices. At the same time, connoisseur consumers are inspired by outstanding professionals, and they try to emulate their professional practice; however, a status 
game take place between them. Some moments, they compete against each other, challenging the knowledge and subcultural capital of the other.

By examining connoisseurship consumption, our research contributes to prior studies on serious leisure consumption pursuits (Belk, 1988; Belk \& Costa, 1998; Kozinets, 2001; Moisio et al., 2013; Thomas et al, 2013; Tumbat $\&$ Belk, 2011) by explaining the forces that drive the connoisseurship consumption community. Our findings increase our understanding of the connoisseurship consumption community and shed light on the importance of amateurs (connoisseur consumers) to professionals and regular consumers, or consumers who are not engaged in a serious leisure pursuit. Previous research hasn't described or revealed the tensions in Stebbins's professional-amateur-public (P-A-P) system. The identification of the amateur consumer's behavior and the relationship of these amateurs with professionals and with the public during their consumption practices, contributes to the consumer culture field by increasing knowledge of this social consumption phenomenon.

Finally, the connoisseurship consumption community helps us to better understand the dynamics of heterogeneous consumption communities (Thomas et al., 2013). Prior consumption community research has focused on singular producers, but, as the study published by Thomas et al. (2013) reveals, consumption community members are heterogeneous. Drawing on Stebbins's P-A-P system (1979, p.24), we help to advance the study of such communities by revealing the tensions between the members of the community and the production of subcultural and social capital. The enactment tensions (Thomas et al. 2013) between connoisseurs and regular consumers - and between outstanding professionals and regular consumers, and the status games (Üstüner \& Thompson, 2012) between connoisseur consumers and outstanding professionals in the connoisseurship community have been identified and described in this paper.
By navigating these tensions, the members produce and increase their subcultural and social capital online and offline.

Connoisseurship consumption is a rich context that can help shed light on consumer behavior, expanding and developing theory in the consumer culture field. Connoisseur consumers are increasing in many types of marketplace cultures, such as wine, food, and beer. The phenomena detected within connoisseurship consumption community could thus be applied to other beverage or food contexts, as well as be used to identify other possible tensions and forces between the members. Future research can also address the behavior of the connoisseurship consumption community in non-food and nonbeverage contexts, identifying the similarities and differences. These varied applications can provide a greater understanding of the connoisseurship consumption community.

\section{References}

Ahuvia, A. (2005). Beyond the extended self: Loved objects and consumers' identity narratives. Journal of Consumer Research, 32(1), 171-184.

Arnould, E. J., \& Price, L. L. (1993). River magic: Extraordinary experience and the extended service encounter. Journal of Consumer Research, 20(1), 24-25.

Arnould, E. J., \& Wallendorf, M. (1994). Marketoriented ethnography: Interpretation building and marketing strategy formulation. Journal of Marketing Research, 31(4), 484-504.

Audio Café. (2014, February 4). Audio Cafe 005: Customer service pt. 2. Podcast retrieved from http://audiocafepodcast.com/5

Becker, H. S. (1982). Art worlds. Berkeley: University of California Press.

Belk, R. (2013). Extended self in a digital world. Journal of Consumer Research, 40(3), 477-500. 
Belk, R. W. (1988). Possessions and the extended self. Journal of Consumer Research, 15(2), 139-168.

Belk, R. W. (1995). Collecting in a consumer society. London: Routledge.

Belk, R. W., \& Costa, J. A. (1998). The mountain man myth: A contemporary consuming fantasy. Journal of Consumer Research, 25(3), 218-240.

Belk, R. W., Fischer, E., \& Kozinets, R. V. (2013). Qualitative consumer \& marketing research. London: Sage Publcations.

Belk, R. W., Sherry, J. F., \& Wallendorf, M. (1988). A naturalistic inquiry into buyer and seller inquiry at into a buyer swap meet. Journal of Consumer Research, 14(4), 449-470.

Belk, R. W., \& Tumbat, G. (2004). The cult of Macintosh. Consumption, Markets and Culture, 8(3), 205-218.

Bourdieu, P. (1984). Distinction: A social critique of the judgement of taste. Cambridge, MA: Harvard University Press.

Cassia, L., Fattore, M., \& Paleari, S. (2006). Entrepreneurial strategy. Cheltenham, UK: Edward Elgar Publishing.

ChefSteps. (2014). Espresso: The art of extraction. Retrieved from https://www.chefsteps.com/ classes/espresso/landing\#/

Cova, B. (1997). Community and consumption: Towards a definition of the "linking value" of product or services. European Journal of Marketing, 31(3/4), 297-316.

Elliott, C. (2006). Considering the connoisseur: Probing the language of taste. Candian Review of American Studies, 36(2), 229-236.

Firat, A. F., \& Venkatesh, A. (1995). Liberatory postmodernism and consumption the reenchantment of consumption. Journal of Consumer Research, 22(3), 239-267.
Gelber, S. M. (1999). Hobbies. New York, NY: Columbia University Press.

Grinshpun, H. (2013). Descontructing a global commodity: Coffee, culture, and consumption in Japan. Journal of Consumer Culture, 22, 1-22.

Hartmann, J. (2011). Starbucks and the third wave. In S. F. Parker, \& M. W. Austin (Eds.), Coffee-Philosophy for everyone: Grounds for debate (pp. 166-183). Oxford: Willey-Blackwell.

Hennion, A. (2004). Pragmatics of taste. In M. Jacobs, \& N. Hanrahan (Eds.), The blackwell companion to the sociology of culture (pp. 141144). Oxford: Blackwell.

Holt, D. B. (1998). Does cultural capital structure American consumption? Journal of Consumer Research, 25(1), 1-25.

Karababa, E., \& Ger, G. (2011). Early modern ottoman coffeehouse culture and the formation of the consumer subject. Journal of Consumer Research, 37(5), 737-760.

Kjeldgaard, D, \& Ostberg, J. (2007). Coffee grounds and the global cup: Glocal consumer culture in Scandinavia. Consumption, Markets and Culture, 10(2), 175-187.

Kozinets, R. V. (2001). Utopian enterprise: Articulating the meanings of Star Trek's culture of consumption. Journal of Consumer Research, 28(1), 67-88.

Kozinets, R. V. (2002a). Can consumers escape the market? Emancipatory illuminations from burning man. Journal of Consumer Research, 29(1), 20-38.

Kozinets, R. V. (2002b). The screen: Using netnography marketing communities. Journal of Marketing Research, 39(1), 61-72.

Kozinets, R. V. (2014). Netnography: Doing ethnographic research on-line. London: Sage Publications. 
Larson, M. S. (1977). The rise of professionalism. Berkeley: University of California Press.

Leibenstein, H. (1950). Bandwagon, snob, and Veblen effects in the theory of consumers' demand. The Quarterly Journal of Economics, 64(2), 183-207.

Martin, D. M., \& Schouten, J. W. (2014). Consumption-driven market emergence. Journal of Consumer Research, 40(5), 855-870.

McCracken, G. (1988). The long interview. Thousand Oaks, CA: Sage.

McQuarrie, E. F., Miller, J., \& Phillips, B. J. (2013). The megaphone effect: Taste and audience in fashion blogging. Journal of Consumer Research, 4O(1), 136-158.

Miles, M. B., \& Huberman, A. M. (1994). Qualitative data analysis: An expanded sourcebook (2nd ed.). London: Sage Publcations.

Miller, D. (1997). Material culture and mass consumption. New York: Wiley-Blackwell.

Moisio, R., Arnould, E. J., \& Gentry, J. W. (2013). Productive consumption in the classmediated construction of domestic masculinity: Do-it-yourself (DIY) home improvement in men's identity work. Journal of Consumer Research, 40(2), 298-316.

Muniz, A. M., \& O’Guinn, T. C. (2001). Brand community. Journal of Consumer Research, 27(4), 412-432.

Muñiz, A. M., \& Schau, H. J. (2014). Religiosity in the abandoned apple brand community. Journal of Consumer Research, 31(4), 737-747.

Oldenburg, R. (1997). The great good place: Cafes, coffee shops, bookstores, bars, hair salons, and other hangouts at the heart of a community (2nd ed.). Washington: Marlowe \& Company.

Price, L. L., \& Arnould, E. J. (1999). Commercial friendships: Service provider-client in context relationships. Journal of Marketing, 63(4), 38-56.
Rhinehart, R. (2009). What is specialty coffee? Retrieved from http://scaa.org/?page=RicArtp1

Ritzer, G. (2007). The Mcdonaldization of society (5th ed.). New York: Pine Forge Press.

Rook, D. W. (1985). The ritual dimension of consumer behavior. Journal of Consumer Research, 12(3), 251.

Roseberry, W. (1996). The rise of yuppie coffees and the reimagination of class in the United States. American Anthropologist, 98(4), 762-775.

Schouten, J. W., \& McAlexander, J. H. (1995). Subcultures of consumption: An ethnography of the new bikers. Journal of Consumer Culture, 22(1), 43-61.

Simon, B (2011). Not going to Starbucks: Boycotts and the out-Scouring of Politics in the Branded World. Journal of Consumer Culture, 11(2), 145-67.

Smith, M. A. (2011, March 15). Espresso as a lottery ticket. Retrieved from http://ineedcoffee. com/espresso-as-a-lottery-ticket/

Stebbins, R. A. (1979). Amateurs. Beverly Hills: Sage Publications, Inc.

Stebbins, R. A. (1982). Serious leisure: A conceptual statement. The Pacific Sociological Review, 25(2), 251-272.

Stebbins, R. A. (2007). Serious leisure: A perspective for our time. New Brunswick, NJ: Transaction.

Stebbins, R. A. (2012). The idea of leisure: First principles. New Brunswick, NJ: Transaction.

Thomas, T. C., Price, L. L., \& Schau, H. J. (2013). When differences unite: Resource dependence in heterogeneous consumption communities. Journal of Consumer Research, 39(5), 1010-1033.

Thompson, C. J. (1997). Interpreting consumers: A hermeneutical framework for deriving insights 
from the texts of consumers' consumption stories. Journal of Marketing Research, 34(4), 438-55.

Thompson, C. J., \& Arsel, Z. (2004). The Starbucks brandscape and consumers' (anticorporate) experiences of glocalization. Journal of Consumer Research, 31(3), 631-642.

Thompson, C. J., Locander, W. B., \& Pollio, H. R. (1994). The spoken and the unspoken: A hermeneutic approach to understanding the cultural viewpoints that underlie consumers' expressed meanings. Journal of Consumer Research, 21(3), 432-452.

Thompson, C. J., Rindfleisch, A., \& Arsel, Z. (2006). Emotional branding and the value of the doppelganger brand image. Journal of Consumer Research, 70(1), 50-64.
Thornton, S. (1996). Club cultures: Music, media, and subcultural capital. Retrieved from Kindle.

Tumbat, G., \& Belk, R. W. (2011). Marketplace tensions in extraordinary experiences. Journal of Consumer Research, 38(1), 42-61.

Üstüner, T., \& Thompson, C. J. (2012). How marketplace performances produce interdependent status games and contested forms of symbolic capital. Journal of Consumer Research, 38(5), 796-814.

Weinberger, M. F., \& Wallendorf, M. (2012). Intracommunity gifting at the intersection of contemporary moral and market economies. Journal of Consumer Research, 39(1), 74-92.

\section{Supporting Agencies:}

CAPES, process: BEX 5368/13-8. Grant for the first author undertake the international interchange.

\section{Authors:}

1. Ronan Torres Quintão, PhD in Marketing, Getulio Vargas Foundation, São Paulo Busines Administration School. Email: rtquintao@gmail.com

2. Eliane Pereira Zamith Brito, PhD in Business Administration, University of Machester. Email: eliane. brito@fgv.br

3. Russel W. Belk, PhD in Marketing, University of Minnesota. Email: rbelk@schulich.yorku.ca

\section{Contribution of each author:}

\begin{tabular}{|c|c|c|c|}
\hline Contribution & $\begin{array}{c}\text { Ronan Torres } \\
\text { Quintáo }\end{array}$ & $\begin{array}{l}\text { Eliane Pereira } \\
\text { Zamith Brito }\end{array}$ & Russel W. Belk \\
\hline 1. Definition of research problem & $\sqrt{ }$ & $\sqrt{ }$ & $\sqrt{ }$ \\
\hline $\begin{array}{l}\text { 2. Development of hypotheses or research questions ( empirical } \\
\text { studies ) }\end{array}$ & $\sqrt{ }$ & & \\
\hline \multicolumn{4}{|l|}{$\begin{array}{l}\text { 3. Development of theoretical propositions } \\
\text { (theoretical Work) }\end{array}$} \\
\hline 4. Theoretical foundation/ Literature review & $\sqrt{ }$ & $\sqrt{ }$ & $\sqrt{ }$ \\
\hline 5. Definition of methodological procedures & $\sqrt{ }$ & $\sqrt{ }$ & $\sqrt{ }$ \\
\hline 6. Data collection & $\sqrt{ }$ & & \\
\hline \multicolumn{4}{|l|}{ 7. Statistical analysis } \\
\hline 8. Analysis and interpretation of data & $\sqrt{ }$ & & \\
\hline 9. Critical revision of the manuscript & $\sqrt{ }$ & $\sqrt{ }$ & $\sqrt{ }$ \\
\hline 10. Manuscript Writing & $\sqrt{ }$ & & $\sqrt{ }$ \\
\hline
\end{tabular}

